\title{
Teacher Actions Bring up Students' Thoughts in Solving Mathematical Problems
}

\author{
Syaifuddin*, Abdul Halim Fathani, Surahmat \\ Mathematics Education, Faculty of Education and Teachers Training, Islamic University of Malang, Indonesia
}

Received Octomber 15, 2019; Revised November 15, 2019; Accepted November 22 ,2019

Copyright $\odot 2019$ by authors, all rights reserved. Authors agree that this article remains permanently open access under the terms of the Creative Commons Attribution License 4.0 International License

\begin{abstract}
This article aims to describe the actions taken by the teacher to bring out students' thoughts so that students are able to make strategies in solving mathematical problems. Data obtained from direct observation of the research subject when giving actions to students. The subject of the study was the mathematics teacher who was chosen based on special characteristics that fit the purpose of the study. In this study, there are 2 different characteristics when the teacher gives action to students so that students are able to make strategies in solving problems with the story. First, the teacher gives four actions as follows: (1) the teacher asks students to rewrite the problem using their own words, write down what is known and what is asked in the problem; (2) the teacher asks students to turn problems into symbolic problems; (3) the teacher asks students to create symbolic mathematical problems and use operations and procedures in mathematics appropriately to solve problems; (4) the teacher directs students to check the results of problem solving. Second, the teacher gives the following actions: (1) the teacher asks students to write down what is known and what is asked in the problem; (2) the teacher asks students to turn problems into symbolic problems; (3) the teacher asks students to create symbolic mathematical problems and use operations and procedures in mathematics appropriately to solve problems.
\end{abstract}

Keywords Teacher's Action, Student's Thinking, Mathematical Problems

\section{Introduction}

In learning mathematics, teachers usually give questions to students. From that problem, there is a possibility that students will be able to solve the problem and there may be students who have not been able to solve the problem. For students who are able to solve problems, then the problem is not a problem for these students. Conversely, for students who have not been able to solve problems, then the problem is a problem for these students. This is in accordance with the opinion of Hudojo [4] which states that if the answerer can solve the problem, then the problem is not a problem. On the other hand, if the question answering requires organizing knowledge that is not routinely owned, then the problem is a problem. The National Council of Teachers of Mathematics [8] states that mathematical problems are mathematical problems and there are no routine procedures that can be used to solve them.

To solve mathematical problems, mental processes from students are needed. The mental process is a reflection of one's thoughts and mental processes cannot be observed directly. This is in accordance with the statement of Strenberg [9] which states a person's mental processes cannot be observed directly. However, mental processes can be observed through the behavior displayed by the person. Therefore, if students have not displayed through students' skills in making strategies to solve problems, then there is no mental process carried out by these students.

When there is no mental process done by students, the teacher can provide a response so students are able to display through students' skills in making strategies to solve problems. The teacher can decide to respond to the strategies students use to solve problems Jacob [11]. According to Syaifuddin [10], teachers can provide responses when students solve mathematical problems. The response is in the form of assistance given to students. According to Anghiler [6], there are 3 levels in providing assistance, namely: (1) assistance can be provided using everything in the class, (2) assistance can be in the form of explanations, directions for reviewing problems encountered, and directions for restructuring problems faced, (3) assistance provided in the form of direction to develop conceptual thinking. According to Syaifuddin [10], there are 2 different characteristics in the response given by the teacher. First, the response given by the teacher is as 
follows: (1) asking students to pay attention to examples that are similar to the problems faced by students, (2) provide simpler examples of problems faced by students, (3) provide more complex examples of problems faced by students. Second, the response given by the teacher is as follows: (1) asking students to pay attention to examples that are similar to the problems faced by students, (2) provide simpler examples of problems faced by students.

After the teacher responds to students, it does not guarantee students are able to bring up their thoughts to solve mathematical problems. If students have not been able to solve mathematical problems after being given a response by the teacher, the teacher needs to provide actions that can spark students' thinking so that students are able to make strategies to solve these mathematical problems. This is consistent with observations made by the author during the odd semester of the academic year 2017/2018 some students have not been able to solve mathematical problems after the response from the teacher. Likewise, according to Syaifuddin [10], there are still students who have not been able to solve mathematical problems. Therefore, actions are needed for students so students are able to solve mathematical problems.

The actions taken by the teacher aim to make students able to bring up their thoughts so they are able to solve mathematical problems. To solve mathematical problems can be done by understanding the problem, planning to solve the problem, implementing the plan that has been made, and checking the results obtained. This is in accordance with Polya [3] which states that there are 4 (four) steps to solve problems, namely: (1) understanding the problem, (2) making a plan to solve the problem, (3) implementing the plan that has been made, (4) check the results obtained. These four steps are known as Polya steps.

Because of the importance of the actions taken by the teacher to students so that the mathematical problem can be solved by students, then the action needs to be described. Therefore, in this article, the writer will describe the actions taken by the teacher to bring up students' thoughts so that students are able to solve mathematical problems.

\section{Materials and Methods}

\subsection{Mathematical Problems}

A problem in mathematics is a problem or question that raises a challenge to solve the problem or question and in solving it requires creativity, experience, thought or imagination Posamentier\&Stepelman [1]. A problem or question is said to be a problem if someone does not have certain rules that can immediately be used to solve the problem Hudojo [5]. To solve a problem requires creativity, critical, and ready knowledge in a new situation.

A problem usually contains a situation that encourages students to solve it but do not know directly what to do to solve it. If a problem is given to students and the student immediately knows how to solve it correctly, then the problem cannot be said to be a problem Sitorus [7]. On the other hand it states that a mathematical question or problem is a problem depending on each individual student, this means that for certain students a math problem might be a problem while for other students it is not a problem. For example, consider the following problem:

There are 52 students in a class. If there are many male students, there are 7 students more than twice as many female students. Determine many male students and many female students!

The question of the story in this study is a problem for students. Because, students are unable to solve the problems above. The question of the story in this study is a problem for students. Because, students are unable to solve the problems above.

\subsection{Student's Thinking}

According to Baum [2], thoughts are ideas and mental processes. Thinking involves brain manipulation of the information received. In cognitive psychology, thinking is a high level cognitive function. According to the Big Indonesian Dictionary, thinking is to use reason to consider and decide things. Whereas in this study, thinking in solving problems is a mental process in solving problems that are displayed through skills in making strategies.

\subsection{Teacher's Actions}

When students are not able to make strategies in solving problems, the presence of teachers is expected to overcome these problems. The presence of teachers in class is one of the factors that can determine student competence National Council of Teachers of Mathematics [8]. The teacher can provide actions to facilitate students who are experiencing difficulties so students are able to make strategies in solving problems. The teacher must also be able to anticipate and be prepared with responses to facilitate students when students experience obstacles in the thought process.

According to Polya [3], there are steps that need to be taken to solve problems, namely: (1) understanding the problem, (2) planning to solve the problem, (3) solving the problem in accordance with the plan that has been made, and (4) checking return the results obtained. In the step of understanding the problem can be done by writing what is known in the problem, write what is asked in the problem, and rewrite the problem using his own words. While in the step of making a plan to solve the problem, it can be done by choosing a strategy that suits the problem. Because Polya's steps have an important role in helping students solve problems, the actions taken by the teacher so that students are able to make problem solving strategies can be assessed based on Polya's steps. 


\subsection{Methods}

In this study, the authors directly observed the actions taken by research subjects. Observations were made by the author when the research subject took action on students so students were able to bring up their thoughts to make strategies in solving problems. The purpose of this observation is to obtain data about the behavior of the research subjects when giving action. The observed action is the effort made by the research subject so that the student is able to understand the problem, the student is able to plan to solve the problem, the student is able to solve the problem according to the plan that has been made, and the student is able to check the results obtained. In this observation process, the writer records all the events carried out by the research subject when giving action to students.

The research subjects were chosen by setting specific characteristics that fit the purpose of the study. The purpose of this study is as follows describing the actions taken by the research subject so that students are able to come up with their thoughts to make strategies in solving problems. The subjects in this study were 2 mathematics teachers. The two teachers are then symbolized by S1 and S2.

\subsection{Action S1 Raises Students' Thoughts So as to Be Able to Make Strategies for Resolving Mathematical Problems}

To bring up students' thoughts in making strategies in solving problems, There are 4 actions taken by S1, namely (1) directing students to understand problems, (2) directing students to plan problem solving, (3) directing students to carry out plans that are made, (4) directing students to check the results of problem solving. Following is the S1 dialogue when directing students to understand a problem, namely by asking students to rewrite the problem using their own words, writing down what is known and what is asked in the problem.

S1: There is a question "A class has 52 students. If there are many male students, there are 7 students more than twice as many female students. Determine many male students and many female students! "Try to write back the problem in your own words, write what is known and what is asked in the matter.

Students: There are 52 students in the class, there are 7 male students more than twice as many female students, how many male students and many female students. Students: There are 52 students in the class, there are 7 male students more than 7 students out of twice as many female students, how many male students and many female students.

The second S1 action directs students to plan problem solving. S1 directs students to turn problems into symbolic problems by turning problems into problems formed from mathematical symbols. The following dialogues S1 and students:

S1: After knowing what is known and what is asked, what will be done next?

Student : I am still confused sir

S1: Okay. It's a matter of story. Try changing that problem into a symbolic mathematical problem

Student: How to do it, sir?

S1: You turn the problem into a problem formed by mathematical symbols

Student: Oh yes ... if there are many students who are male if I suppose L and many students are female, for example P. How about that, sir?

S1: After knowing what is known and what is asked, what will be done next?

Student : I am still confused sir

S1: Okay. It's a matter of story. Try changing that problem into a symbolic mathematical problem

Student: How to do it, sir?

S1: You turn the problem into a problem formed by mathematical symbols

Student: Oh yes ... if there are many students who are male if I suppose L and many students are female, for example P. How about that, sir?

The third action S1 directs students to carry out problem solving plans. S1 directs students to make symbolic mathematical problems and observes symbolic mathematical problems created and directs students to use operations and procedures in mathematics appropriately to solve problems. The following dialogues S1 and students:

S1: What is the symbolic mathematical form of "a class of 52 students"?

Student: Because there are male and female students in the class, the symbolic mathematical form of "a class of 52 students" is $L+P=52$

S1: Please work on elimination or other methods

Student: Like this

$L+P=52$

$L=7+2 P$

S1: You see $L+P=52$ and $L=7+2 P$ these two equations are not the same. Can it be eliminated?

Student: You can't

S1: Then how can you be eliminated?

Student: Must be likened

S1: Do you mean the same?

Student: Equation $L=7+2 P$ is changed to $L-2 P=7$

S1: Okay right. Now try to do the two equations?

Student: Like this

$L+P=52$

$L-2 P=7$

S1: Why is it reduced?

Student : Because to eliminate L.

S1: Try to continue

Student: Like this

$L+P=52$

$L-2 P=7$

$3 P=45$ 
$P=15$

and to find $L$ which is 52 minus 15 so that $L=37$. Because $P$ is assumed by many women and $L$ is assumed by many men, so many women are 15 people and many men are 37 people

The fourth action $\mathrm{S} 1$ directs students to check the results of problem solving. The following dialogues S1 and students:

S1: From the results that you have obtained, are there really 52 students in the class? Try to put the results of your work into the equation

Student: Yes, there are 37 male students and 15 female students. So, there are 52 people in the class

S1: Is it true that there are 7 male students more than 2 times the number of female students? Try to put the results of your work in the equation

Student: Right, many female students are 15 people. Meaning 2 times the number of female students is 30 . While there are many male students 37. So, it is true that there are 7 male students more than 2 times the number of female students

S1: Fine, then your settlement strategy is correct.

\subsection{Action S2 Raises Students' Thoughts So as to Be Able to Make Strategies for Resolving Mathematical Problems}

To bring up students' thoughts in making strategies to solve problems, there are 3 actions taken by S2, namely (1) directing students to understand problems, (2) directing students to plan problem solving, (3) directing students to carry out plans that are made. Following is the S2 dialogue when directing students to understand a problem, namely by asking students to write down what is known and what is asked in the problem:

S2: A class of 52 students. If there are many male students, there are 7 students more than twice as many female students. Determine many male students and many female students! Write down what is known and what is asked!

Students: There are 52 students in the class, there are 7 male students more than twice as many female students, how many male students and many female students

The second S2 action directs students to plan problem solving. S2 directs students to turn problems into symbolic problems by assuming male and female students with a variable. The following dialogues $\mathrm{S} 1$ and students:

S2: That's a matter of story. That problem turns into a symbolic mathematical problem

Student: How to do it?

S2: Change that problem into a problem formed by mathematical symbols

Student: Oh yes ... if there are many male students if I suppose L and many of my female students, for example P. How is that, sir?

The third S2 action directs students to carry out the problem solving plan. S2 directs students to make symbolic mathematical problems and asks students to observe symbolic mathematical problems that are made and directs students to use mathematical operations and procedures to solve problems. The following dialogue is S2 and students:

S2: How about 52 symbolic mathematical problem forms in a class?

Student: There are male and female students in Class. The form of the symbolic problem is $L+P=52$

S2: Please work with elimination or other methods

Student: Like this

$L+P=52$

$L=7+2 P$

S2: You see $L+P=52$ and $L=7+2 P$ these two equations are not the same. Can it be eliminated?

Student: You can't

S2: Then how can you be eliminated?

Student: Must be likened

S2: You mean the same?

Student: Equation $L=7+2 P$ is changed to $L-2 P=7$

S2: Okay, right. Now try to do the two equations?

Student : Like this

$L+P=52$

$L-2 P=7$

S2: Why is it reduced?

Student: Because to eliminate L.

S2: Try to continue

Student: Like this

$L+P=52$

$L-2 P=7$

$3 P=45$

$P=15$

and to find $L$ which is 52 minus 15 so that $L=37$. Because $P$ is assumed by many women and $L$ is assumed by many men, then there are 15 women and many men are 37 people.

\section{Conclusions}

There are 2 different characteristics when the teacher gives action to bring up students' thoughts so that students are able to make strategies in solving problems. First, to bring up students' thoughts so that they can make strategies in solving problems, there are 4 actions given. Second, to bring up students 'thoughts so that they can create problem solving strategies, there are 3 actions given. There are 2 different characteristics when the teacher gives actions to bring up students' thoughts so that students are able to make strategies in solving problems. First, to bring up students' thoughts so that they can make strategies in solving problems, there are 4 actions given. Second, to bring up students' thoughts so they can create a problem solving strategy, there are 3 actions given.

Four actions given by the teacher are as follows: (1) the teacher directs students to understand the problem, namely 
by asking students to rewrite the problem using their own words, writing down what is known and what is asked in the problem. Polya [3] states that an indicator is able to understand a problem including being able to rewrite the problem by using his own words, writing down what is known and what is asked in the problem. (2) The teacher directs students to plan problem solving, namely asking students to turn problems into symbolic mathematical problems by turning problems into problems formed from mathematical symbols. Polya [3], a mathematical model is one of the strategies that can be used to solve problems. (3) The teacher directs students to carry out problem solving plans, namely by asking students to create symbolic mathematical problems and observe the forms of symbolic mathematical problems obtained and use operations and procedures in mathematics appropriately to solve problems. (4) The teacher directs students to check the results of problem solving.

The three actions given by the teacher are as follows: (1) The teacher lets students understand the problem, namely by asking students to rewrite the problem using their own words, writing down what is known and what is asked in the problem. (2) The teacher directs students to plan problem solving, i.e. ask students to turn problems into symbolic mathematical problems. (3) The teacher directs students to carry out problem solving plans, namely asking students to make symbolic mathematical problems and to use operations and procedures in mathematics appropriately to solve problems.

\section{REFERENCES}

[1] A.S. Posamentier, A.S., J. Stepelman. Teaching Secondary School Mathematics Teacniques and Enrichment Units, Merril Publishing Company, Ohio, 2002

[2] E. Baum. What is Thought, Chapter Two: The Mind is a Computer Program, MIT Press, New York, 2004

[3] G. Polya. How To Solve it, Second Edition, Princeton University Press, New Jersey, 1973

[4] H. Hudojo. Belajar Mengajar Matematika, Depdiknas, Proyek P2LPTK, Jakarta, 1988

[5] H. Hudojo. Common Textbook Pengembangan Kurikulumdan Pembelajaran Matematika, JICA, Malang, 2003

[6] J. Anghileri. Scaffolding Practices That Enhance Mathematics Learning. Journal of Mathematics Teacher Education: Springer, Vol. 9, 33-52, 2006

[7] J. Sitorus. Pembaharuan Pengajaran Matematika Sekolah, Tarsito, Bandung, 2009

[8] National Council of Teachers of Mathematics. Principles and Standards for School Mathematics, NCTM, Reston, 2000.
[9] R.J. Sternberg. Cognitive Psychology, Thomson Wadsworth, Belmont, 2006.

[10] Syaifuddin, Purwanto, Sudirman, M. Muksar. Teachers' Responses on Students' Understanding when Students Resolve Mathematics, Universal Journal of Educational Research, Vol. 7, No. 10, 2239-2242, 2019

[11] V.R. Jacobs, L.L.C. Lamb, R.A. Philipp. Professional Noticing of Children's Mathematical Thinking, Journal for Research in Mathematics Education, Vol. 41, No. 2, 169-202, 2010. 